\title{
Elucidation of the taxonomy and pathological status of Pyricularia associated with banana blast in Australia
}

\author{
Mike F. Male • Yu Pei Tan • Lynton L. Vawdrey • \\ Roger G. Shivas
}

Received: 27 January 2011 / Accepted: 19 April 2011 / Published online: 24 May 2011

(C) Australasian Plant Pathology Society Inc. 2011

\begin{abstract}
In September 2010, banana blast symptoms were observed on leaves of tissue cultured banana plantlets cv. Dwarf Cavendish. The pathogen was identified as Pyricularia angulata, based on disease symptoms, fungal morphology, pathogenicity and ITS sequencing. Previous Pyricularia spp. samples and records were confirmed as being $P$. angulata. This report elucidates the identity and pathological status of $P$. angulata in Australia.
\end{abstract}

\section{Keywords Pyricularia angulata $\cdot$ Banana blast $\cdot$ Musa .} Cavendish

Approximately $80 \%$ of Australia's banana production occurs in the wet tropical coast region of northern Queensland near the towns of Innisfail and Tully. This region receives abundant annual rainfall of between 3570 and $4490 \mathrm{~mm}$, most of which falls during the warm $\left(22-31^{\circ} \mathrm{C}\right)$ summer months (Dec-Feb), providing favourable environmental conditions for the development and proliferation of many fungal diseases. Over the past decade, the pursuit of uniform banana plants free of diseases has increased the use of tissue-cultured plantlets in the establishment of new banana plantings. Dense populations of banana plantlets tend to be raised in plastic covered plant houses under overhead irrigation, which often creates a poorly ventilated and damp environment. Sequential plantings of banana plantlets throughout the year further encourage fungal

\footnotetext{
M. F. Male $(\bowtie) \cdot$ L. L. Vawdrey

Plant Pathology, Department of Employment, Economic

Development and Innovation, Centre for Wet Tropics Agriculture,

South Johnstone 4859 QLD, Australia

e-mail: mike.male@deedi.qld.gov.au

Y. P. Tan • R. G. Shivas

Plant Pathology Herbarium, DEEDI, Ecosciences Precinct,

Dutton Park 4102 QLD, Australia
}

diseases as they provide an ongoing source of a susceptible host.

In September 2010, leaf symptoms were observed on young tissue cultured banana plantlets cv. Dwarf Cavendish (AAA; Cavendish subgroup) at two nurseries in north Queensland. Symptoms included severe spotting on all leaves, death of some leaves and in severe cases, death of the whole plant. Lesions started as small, light tan coloured spots $1 \mathrm{~mm}$ in diam. that developed into circular or elliptical tan coloured spots 3-4 $\mathrm{mm}$ in diam. with a yellow margin. Mature lesions were brown in colour, $8-10 \mathrm{~mm}$ in diam., with a slightly darker margin and zonate appearance (Fig. 1). Adjacent lesions coalesced to produce large areas of necrotic tissue.

Pieces of diseased leaves were surface-sterilised by immersion in $1.0 \%$ sodium hypochlorite solution (Northern Chemicals, Cairns, Australia) for $1 \mathrm{~min}$., rinsed in sterile distilled water and dried between pieces of sterile paper in a laminar flow cabinet. Small sections of diseased tissue were taken from the margin of lesions and placed onto $2 \%$ potato dextrose agar (Bacto Laboratories, Liverpool, Australia) amended with streptomycin sulfate $(40 \mathrm{U} / \mathrm{mL})(\mathrm{PDA}+\mathrm{S})$ and incubated in the dark for $48 \mathrm{~h}$ at $27^{\circ} \mathrm{C}$. Resulting colonies were subcultured onto PDA $+\mathrm{S}$ and incubated for $48 \mathrm{~h}$ in the dark at $27^{\circ} \mathrm{C}$ before being placed under near-UV light with a $12 \mathrm{~h}$ photoperiod for a further 5 day to induce sporulation. Similar fungal colonies were consistently recovered and identified on the basis of conidial morphology as belonging to Pyricularia sp. (Ellis 1971). Conidiophores were pale brown, darker towards the base, up to $120 \mu \mathrm{m}$ long and $4 \mu \mathrm{m}$ wide, sometimes branched, straight to flexuous. Conidiogenous cells were polyblastic, integrated, terminal, sympodial, geniculate, with denticles up to $1.5 \mu \mathrm{m}$ long separated by a septum. Conidia were ovoid to obpyriform, 19-22 $\times 6.5-8 \mu \mathrm{m}$, subhyaline to pale brown, smooth, 

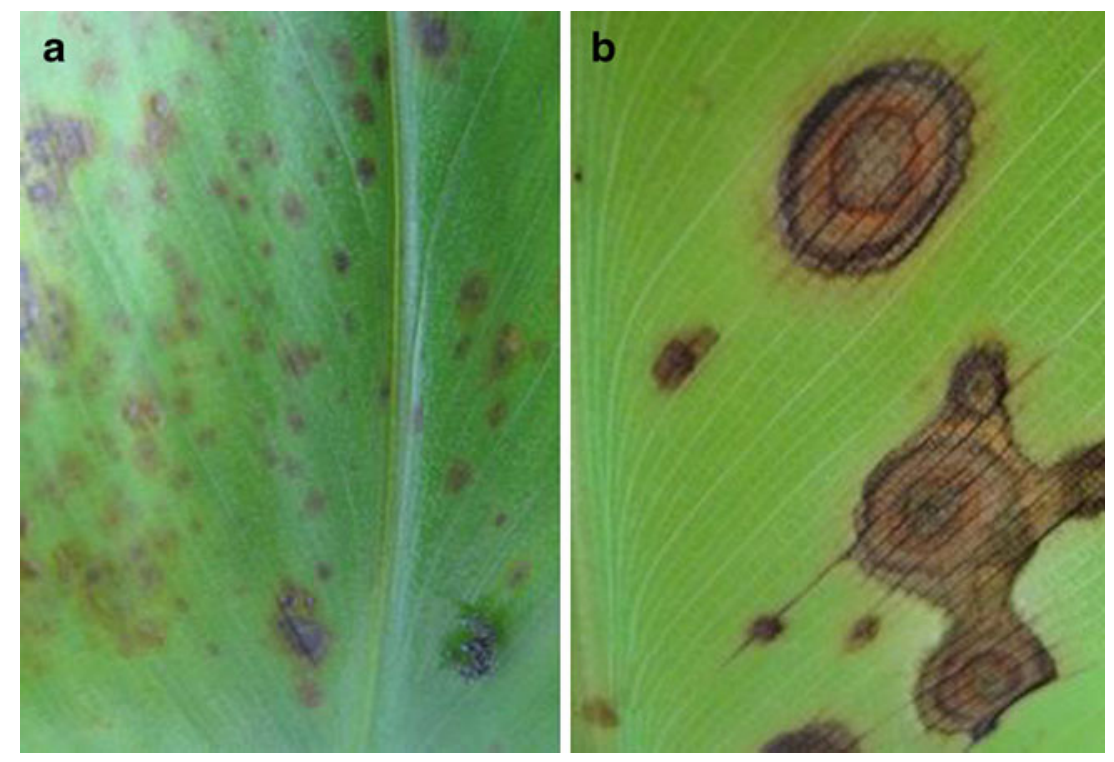

Fig. 1 Pyricularia angulata lesions of banana blast on Dwarf Cavendish banana. (a) early stage; (b) close-up of mature lesions, zonation apparent

thin-walled, 2-septate, hilum protuberant (Fig. 2). Monoconidial cultures were produced by gently brushing over a sporulating culture with a sterile camel hair paintbrush and tapping the brush over PDA $+\mathrm{S}$ culture plates. After $12 \mathrm{~h}$, germinating conidia were transferred to fresh $\mathrm{PDA}+\mathrm{S}$ culture plates. Two monoconidial cultures (BRIP 53746 and BRIP 53869) were subsequently deposited in the Plant Pathology Herbarium, Dutton Park (BRIP).

For DNA extraction, mycelium from isolate BRIP 53746 was placed in a $2.0 \mathrm{~mL}$ safe-lock tube (Eppendorf, Hamburg, Germany). The equivalent of $0.5 \mathrm{~mL}$ of $0.5 \mathrm{~mm}$ glass beads (Daintree Scientific, St Helens,
Australia) was added and the mycelium was lysed using the Tissue Lyser (Qiagen, Hilden, Germany) for $1 \mathrm{~min}$ at $30 \mathrm{hz} / \mathrm{s}$. DNA was extracted from this mixture using the Gentra Puregene kit (Qiagen), following the manufacturer's instructions. PCR amplification of the internal transcribed spacer (ITS) region was conducted using the Phusion HighFidelity PCR Master Mix (Finnzymes, Espoo, Finland), which consisted of $25 \mu \mathrm{l}$ of $2 \times$ Master Mix with HF Buffer, $1 \mu \mathrm{l}$ each of $10 \mathrm{mM}$ of primers ITS1 (5'-TCCGTAGGT GAACCTGCGG-3') and ITS4 (5'-TCCTCCGCTTATTGA TATGC-3') (White et al. 1990), and $1 \mu$ of DNA template. PCR products were amplified in a Bio-Rad C1000 thermal
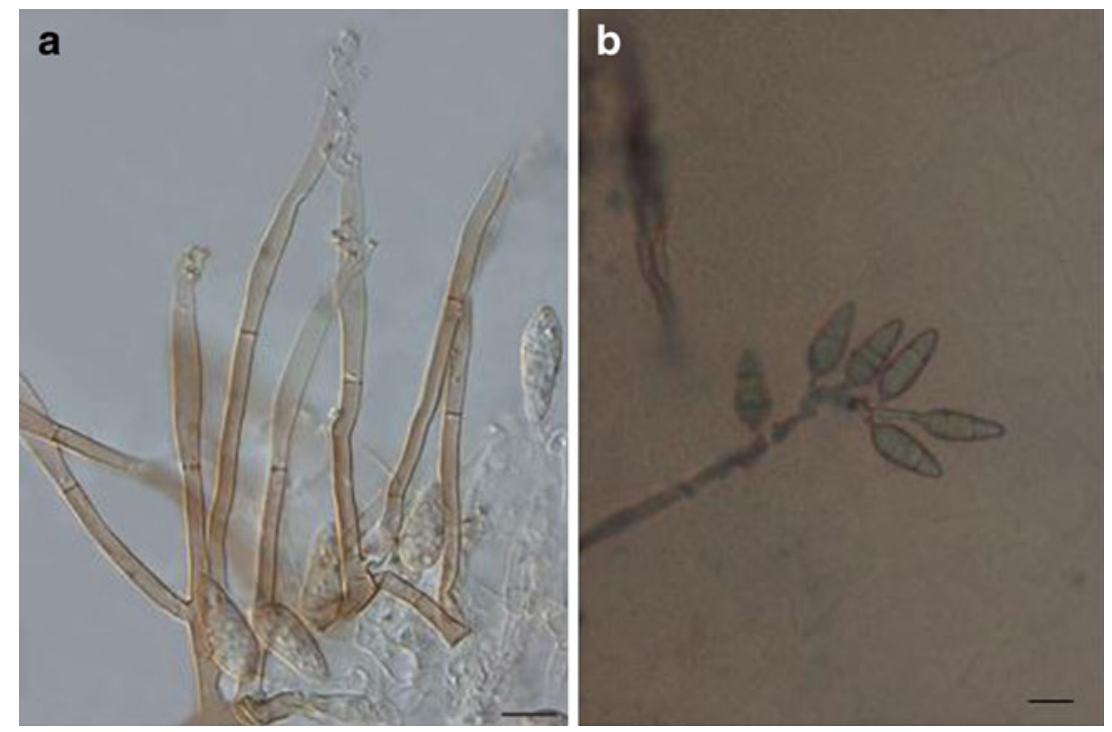

Fig. 2 Pyricularia angulata. a denticulate conidiophores; b conidiophore bearing conidia Bars $=10 \mu \mathrm{m}$ 
cycler (Bio-Rad, Hercules, USA) using the following conditions: $98^{\circ} \mathrm{C}$ for $30 \mathrm{~s}, 30$ cycles at $98^{\circ} \mathrm{C}$ for $10 \mathrm{~s}, 55^{\circ} \mathrm{C}$ for $30 \mathrm{~s}, 72^{\circ} \mathrm{C}$ for $30 \mathrm{~s}$, followed by a $5 \mathrm{~min}$ final extension at $72^{\circ} \mathrm{C}$. The products were purified using the QIAquick PCR Purification Kit (Qiagen). Purified PCR products were sequenced by Macrogen Incorporated (Seoul, Korea) using the AB 3730xl DNA Analyser (Applied Biosystems, Foster City, USA). The sequence obtained (Genbank accession JF719830) was compared to the nucleotide sequence database (GenBank) using the nucleotide query BLASTn accessed via the National Centre for Biotechnology Information website (http://www.ncbi.nlm.nih.gov/). The ITS sequence of BRIP 53746 was identical to GenBank accession AY265322 Pyricularia angulata strain NBRC9625.

Conidia from a sporulating monoconidial culture (BRIP 53746) were removed with a camel-hair paintbrush and dispersed across V8 agar (Campbells, Silverwater, Australia) (V8) by tapping the brush gently on the side of the petri dish. The culture was then incubated in the dark for $48 \mathrm{~h}$ at $27^{\circ} \mathrm{C}$ and placed under near-UV light for a further 5 day at $26^{\circ} \mathrm{C}$. To test for pathogenicity, a conidial suspension was obtained by flooding a culture plate with $1 \mathrm{~mL}$ sterile distilled water and using a glass hockey stick to dislodge the conidia. A further $1 \mathrm{~mL}$ of sterile distilled water was used to rinse the plate into a sterile beaker. The spore suspension was diluted to $10 \mathrm{~mL}$ with sterile distilled water before being passed through sterile muslin and the spore concentration quantified with a haemocytometer. The spore suspension was estimated to be $9 \times 10^{4}$ conidia $/ \mathrm{mL}$. A Preval portable atomiser (Precision Valve Corporation, New York, USA) was then used to apply the spore suspension to both abaxial and adaxial leaf surfaces of 14-wk-old tissue cultured 'Dwarf Cavendish' banana plantlets. Control plantlets were sprayed with sterile water only. To replicate growing conditions often found in nursery plant houses during disease outbreaks and minimise the risk of natural infection, plantlets were grown in a Perspex humidity chamber for 6 week prior to and after inoculation at $26^{\circ} \mathrm{C}$ under artificial light [1× Philips TLD 36W 850 fluorescent tube (Koninklijke Philips Electronics N.V., Amsterdam, Netherlands), 1× Hagen Aqua-Glo 40W fluorescent tube (Rolf C Hagen Inc., Montreal, Canada)] with a 14:10 photoperiod. Humidity was maintained at $>90 \%$ with a Faran H-15 humidifier (Faran, South Korea) programmed to run for 2 min, 15 times per day. Inoculated plants developed typical symptoms of banana blast within 5 day and the control plants remained healthy. Following the same procedure described earlier, fragments of diseased tissue were placed on $\mathrm{PDA}+\mathrm{S}$ culture media and the resulting fungal colonies were identified morphologically as $P$. angulata thereby fulfilling Koch's postulates.

The growth rate and colony characteristics of $P$. angulata were determined by taking a single $5 \mathrm{~mm}$ mycelial/agar plug from the growing margin of a 10-d-old single spored culture growing on PDA $+\mathrm{S}$ (BRIP 53746) and placing it onto V8, PDA, corn meal agar (Bacto Laboratories) (CMA) and potato carrot agar (PCA) under near-UV light at $26^{\circ} \mathrm{C}$. Twelve replicate plates were used per treatment. Colonies were measured and the mean colony diameter calculated after 13 day. Colonies on PDA and V8 agar were circular, up to $60 \mathrm{~mm}$ diam. white to greyish, darker towards the centre, flat to loosely floccose with irregular tufts of white mycelium; margin smooth, entire; abundant sporulation towards the centre of colonies on V8, sparse on PDA. Colonies on PCA were circular up to $72 \mathrm{~mm}$ diam., uniformly grey to hyaline; flat, aerial mycelium absent; slight, regular radial furrows; margin smooth, entire; sporulation almost entirely absent. Colonies on CMA were circular up to $57 \mathrm{~mm}$ diam.; highly variable growth characteristics, white to grey to hyaline, flat to loosely floccose, some colonies tightly floccose with dense spongy tufts of white mycelium; regular radial furrows present in some colonies, absent in others; margin smooth, entire; sporulation sparse to absent.

Pyricularia species cause the disease known as 'blast' on a wide range of mostly monocotyledonous plant species worldwide. The most economically important species being P. grisea, the causal agent of blast disease in rice (e.g. Hashioka 1972). Pyricularia spp. have been reported on bananas (Musa spp.) in various parts of the world including Australia (Hashioka 1971; Hoette 1936; Kim et al. 1987; Meredith 1962, 1963).

The description of the organism given in this paper is very similar to the descriptions of $P$. grisea, found to be responsible for pitting disease in bananas in Australia (Hoette 1936) and Central America (Meredith 1963). Hashioka (1971) observed morphological differences between three isolates of Pyricularia and reassigned $P$. grisea occurring on Musaceae to its own species, $P$. angulata. Further, Kim et al. (1987) found $P$. angulata to be pathogenic only on banana plants whereas $P$. grisea isolated from Digitaria sanguinalis was not. More recently, molecular research has demonstrated the differences between $P$. angulata, P. grisea and 39 other Pyricularia species and allied genera (Bussaban et al. 2005). This suggested that the original identifications from Hoette (1936) in Australia and Meredith (1963) of P. grisea were most likely $P$. angulata.

Two other specimens of Pyricularia sp. isolated from Musa sp. and lodged with BRIP were examined. One of these, BRIP 15526 from leaf spot on banana cv. Cavendish was collected at Tully, Qld in 1986 and was morphologically identical to P. angulata. The other, BRIP 5641, deposited in 1950 consisted of two dried microscope slides that could not be reconstituted. This report elucidates the identity and pathological status of $P$. angulata in Australia. 


\section{References}

Bussaban B, Lumyong S, Lumyong P, Seelanan T, Park DC, McKenzie EHC, Hyde KD (2005) Molecular and morphological characterization of Pyricularia and allied genera. Mycologia 97:1002-1011. doi:10.3852/mycologia.97.5.1002

Ellis MB (1971) Dematiaceous hyphomycetes. CAB, Surrey

Hashioka Y (1971) Notes on Pyricularia I. Three species parasitic to Musaceae, Cannaceae and Zingiberaceae. Trans Mycol Soc Japan $12: 126-135$

Hashioka Y (1972) Fine structure of the rice blast. Res Bull Fac Agr Gifu Univ 33:65-73
Hoette S (1936) Pitting disease of bananas in Australia. Proc Roy Soc Vic 48:90-95

Kim WG, Kim CK, Lee EJ (1987) Banana blast caused by Pyricularia angulata Hashioka. Korean J Plant Pathology 3:114-119

Meredith DS (1962) Pyricularia musae Hughes in Jamaica. Trans Brit Mycol Soc 45:137-142

Meredith DS (1963) Pyricularia grisea (Cooke) Sacc. causing pitting disease of bananas in Central America. Ann appl Biol 52:453-463

White TJ, Bruns T, Lee S, Taylor JW (1990) Amplification and direct sequencing of fungal ribosomal RNA genes for phylogenetics. In: Innis MA, Gelfand DH, Sninsky JJ, White TJ (eds) PCR Protocols: a guide to methods and applications. Academic, New York, pp 315-322 